\title{
BUILDING INTERPERSONAL ABILITY OF ELEMENTARY SCHOOL STUDENTS BY PLAYING TRADITIONAL GAME IN DIGITAL ERA
}

\author{
Vina Anggia Nastitie Ariawan ${ }^{1}$, Uus Kuswendi ${ }^{2}$, Subarkah ${ }^{3}$ \\ 'SDN Bantarmangu 01, Indonesia, 2IKIP Siliwangi, Indonesia \\ ${ }^{3}$ SDN 13 Kerinci Kanan, Riau, Indonesia \\ 1vivianatsir@gmail.com
}

\begin{abstract}
Nowadays, students prefer to have online game rather than traditional one. Online game led to the lack of student's interaction with people around them, they have high individualistic, and shirk responsibility. Traditional game can be an alternative to decrease bad effects of online game. Consequently, this research aims to build interpersonal ability of elementary school students by doing traditional game. This research employed action research method with fitth grade students as its subject. Interpersonal ability which showed in this research was measured by observation meanwhile the instruments of observation consist of field note and rating scale. The outcome from this research was analysed by thematic analysis meanwhile the data was validated by triangulation. Referring to research's findings, researcher concludes that traditional game offer meaningful activities and different experiences to the students. Traditional game motivate students to doing physical acitivities and make interaction with peers. Moreover, a meaningful moral values will evolve among the students by themselves. Traditional game can be used as media to building interpersonal ability of students. Besides that, teacher can introduce the traditional game to students to keep the local wisdom that almost wiped out.
\end{abstract}

Keywords: elementary school, interpersonal ability, students, traditional game.

\section{ABSTRAK}

Saat ini, siswa lebih suka memiliki game online daripada game tradisional. Game online menyebabkan kurangnya interaksi siswa dengan orang-orang di sekitar mereka, memiliki individualistis tinggi, dan mengelak dari tanggung jawab. Game tradisional dapat menjadi alternatif untuk mengurangi efek buruk dari game online. Tujuan penelitian ini bertujuan untuk membangun kemampuan interpersonal siswa sekolah dasar dengan melakukan permainan tradisional. Penelitian ini menggunakan metode penelitian tindakan dengan siswa kelas $\mathrm{V}$ sebagai subjeknya. Kemampuan interpersonal yang ditunjukkan dalam penelitian ini diukur dengan observasi sedangkan instrumen pengamatan terdiri dari catatan lapangan dan skala penilaian. Hasil dari penelitian ini dianalisis dengan analisis tematik sedangkan data divalidasi dengan triangulasi. Mengacu pada temuan penelitian, peneliti menyimpulkan bahwa permainan tradisional menawarkan kegiatan yang 
bermakna dan pengalaman yang berbeda bagi siswa. Permainan tradisional memotivasi siswa untuk melakukan kegiatan fisik dan melakukan interaksi dengan teman sebaya. Selain itu, nilai-nilai moral yang bermakna akan berkembang di antara para siswa sendiri. Permainan tradisional dapat digunakan sebagai media untuk membangun kemampuan interpersonal siswa. Selain itu, guru dapat memperkenalkan permainan tradisional kepada siswa untuk menjaga kearifan lokal yang hampir musnah.

Keywords: Sekolah dasarr, kemampuan interpersonal, permainan tradisional

\section{A. Introduction}

The development of science and technology influences the lifestyle of today's society. The progress of science and technology signifies the emergence of a new era called the digital era. The presence of science and technology makes it easier for people to communicate with each other, develop themselves, and improve the economy (Stander, 2011). The digital era has also influenced the revitalization of the world of education. The teacher can optimize the learning process through multimedia utilization. The existence of science and technology greatly helps teachers and students develop intelligence, explore appropriate resources, and support career advancement. However, the presence of the digital era does not always have a positive impact on society. There are negative impacts of the emergence of the digital era such as low social interaction and low individual interpersonal ability. This can be seen from the phenomenon that is rife in the community. Although technology makes it easier for people to communicate with friends or family in a distant place, it also makes individuals not interact with their closest people (Sahin, 2011).

For example, a mother is busy playing cellphones to communicate with her co-workers but she does not take the time to share stories with her children. Such behavior will cause children not to feel their existence valued so that they often show disturbing behavior (Isangedighi, 2007).

The behavior shown by the child is a form of protest because he or she feels that he or she does not get enough attention. Things get worse when parents assume that children want to play cellphones so they facilitate children with cell phones. 
Lack of attention from parents results in uncontrolled cellphone use and low interest in children to socialize with peers or those around them. Unfortunately, people nowadays consider this behavior to be natural so that there is no awareness to pay attention to children (Lee, 2013).

Interpersonal ability is a person's social competence to build and maintain social relations so that both parties are in a mutually beneficial situation (Safaria, 2005). Interpersonal ability enables students to develop approaches, influences, and create relationships with others. School is a place for students to develop their interpersonal ability because they interact more with peers and others in the school environment. The teacher has a vital role to build students' interpersonal abilities through the learning process or other supporting activities (Berger \& Cortez, 2012). Meanwhile, Joyce and Weill explain that the development of interpersonal abilities of elementary school students should not be taught in the form of subjects but it should be cross-subject objectives (Joyce, 2013). This is because attitudes and values are not internalized through the provision of information but through an appreciation that accumulates from concrete experiences (Syahniar, 2008) . Referring to this opinion, one of the teacher's efforts in developing students' interpersonal ability can be done through traditional games. This statement is reinforced by the Playplus Team which explains that alternative education is to optimize students' social development through traditional games (TPI, 2017). The results of the survey conducted by Khilmiyah in Yogyakarta elementary school found the fact that as many as $78 \%$ of students had low interpersonal ability and were shown by low attitudes of responsibility, ability to overcome conflict, and tolerance among students (Khilmiyas, 2011).

On the other hand, the results of the study by Lestari and Siregar prove that traditional games are effective in improving the social skills of elementary school students (Lestari \& Siregar, 2017). Social skills that arise when students play traditional games are interaction skills, self control, empathy, teamwork, and mutual respect. Traditional games are very useful for elementary school students, 
especially when they are in their infancy. Traditional games will train agility, strategic thinking, and interaction. Through traditional games, students will get to know the game that comes from their birthplace and foster a love for the nation's culture. Therefore, traditional games allow students to build interpersonal ability. Referring to the results of previous studies, the researcher aims at building interpersonal ability of elementary school students through traditional games.

\section{B. Literature Review}

\section{a. Interpersonal Ability}

Parenting patterns, lack of playing facilities, and environmental conditions also influence children's social development (Goh, et.al, 2015). In the digital era, parents prefer to buy children toys rather than to monitor children playing outside with their peers. Negative thinking and lifestyle in the digital era cause parents to worry about indecent social interaction. Therefore, parents facilitate children with various playing tools rather than letting them play with friends. The lack of playing facilities also affects the lack of interest of children to play outside.
Construction of buildings for economic activities or luxury residences causes a reduction of vacant land for children to play. This results in a lack of playing activities for children outside the home even though outdoor activities with peers are very beneficial for their social development. Meanwhile, environmental conditions that are less supportive also trigger the children's low interest in playing traditional games. At present, many parents live in exclusive residences whose residents have high individual attitudes and lack of friendship so that children do not have playmates. Thus, many children prefer to play at home rather than outside with their peers (Kovacovic \& Opic, 2014).

One of important aspect that have to be developed in elementary school is interpersonal ability. Interpersonal ability is the ability of children to relate well to their environment so they can be accepted by their environment or group (Taufik, 2013). Interpersonal ability enables students to understand and communicate with others, see differences in others, maintain relationships with others, and understand their role in a group. 
Interpersonal ability are important for students to socialize with those around them (Hakim, 2018). Students who have high interpersonal ability are shown by often interacting with other people both with peers or adults. Students can influence friends to follow their goals, stand out in group activities, and be able to work together well (Siregar, 2014).

Interpersonal ability can be showed with humor that makes people around them entertained (Martin, 2007). Interpersonal ability has the urgency to (a) establish interpersonal relationships and cooperation so that individuals can understand and foster relationships by respecting differences; (b) play a role in aspects of individual social life, especially in making friends. Conversely, students who have low interpersonal ability are expected to experience many obstacles to their social world. Low interpersonal ability cause students to tend to be insensitive, selfish, uncaring, and easily offensive. In addition, the impact of low interpersonal ability will shape the antisocial personality of students. Interpersonal ability in this study divides three components based on Bar-On which consists of empathy, social responsibility, and interpersonal relations (Sparrow \& Knight, 2006).

Empathy is a mental component needed by each individual. Empathy is the change in one's imagination into the thoughts, feelings, and behavior of others. Empathy makes the individual imagine himself in other people's situations without losing control (Padykula \& Horwitz, 2012). Furthermore, social responsibility is an attempt to play a role in the group seriously. Social responsibility is an action taken by an individual in meeting needs without disturbing others. For example, when an individual acts as a leader, students can carry out their duties as a leader well. In the school environment, the attitude of responsibility can be shown by students through the completion of tasks both independently and in groups. Meanwhile, interpersonal relations are the ability to foster relationships with other people in a good way. Every individual needs interaction with other people or can be said to require relationships with other people (Taufik, 2013). If an individual can build relationships well then they 
can build relationships effectively and achieve their personal goals.

Interpersonal ability can be developed through various activities such as extracurricular activities. Sundari's study found that interpersonal abilities of elementary school students developed well through scouting extracurricular activities (Sundari, 2015). Students who actively participate in scout extracurricular shows better interpersonal ability than students who are less active in scout extracurricular activities. Scouts train students to care for friends, behave politely, and are responsible for the tasks assigned. Referring to the results of the study, the teacher can develop students' interpersonal ability through activities outside the classroom. Nevertheless, in this study researchers will build students' interpersonal ability through traditional games.

\section{b. Traditional Game}

Entering the digital era, elementary school students experience many changes in their mindset and lifestyle. Elementary school students are adept at using devices and showing addictive attitudes. In the digital era, the majority of elementary school students are no longer engrossed in activities that are beneficial for physical growth and the formation of their personality (Boyd, 2014). In the 1990s, elementary school students were very happy to play with their peers. Every afternoon or during the holidays elementary school students do many traditional games in the field or in the yard of their house. Interpersonal ability cannot just appear but it will be well formed through activities that involve many groups.

Haryati and Julia conducted research to develop early childhood interpersonal ability through playing balloons in pairs (Hayati \& Julia, 2018). The development of children's interpersonal ability is shown when children are able to take part in paired balloon games according to the direction of the teacher. Before the teacher invites children to do balloon games, they only play with close friends or form a group of friends. However, after the teacher invites the childrens to do balloon games in pairs by randomizing the couple, they unwittingly establish new friendships with other friends. Children's interpersonal ability show good 
development from each meeting up to sixty percent. Referring to the results of previous studies, researchers assume that traditional games can develop interpersonal ability of elementary school students.

Traditional games are game activity that develops from a group of people. Traditional games are often used as a type of game that has original regional characteristics and adapted to local cultural traditions. Elements of folk games, children's play, and art can be internalized in traditional games (Agustin, 2013). Traditional games have several aspects such as (a) physical aspects consisting of strength, endurance, and flexibility; (b) psychic aspects in the form of elements of thinking, counting, intelligence, ability to make tactics, ability to overcome obstacles, memory, and intelligence; (c) social aspects include cooperation, regularity, mutual respect, reciprocity, and shame to cheat (Andriani, 2012). The following is a description of the traditional games played by students during the study.

\section{Ucing Sumput}

Ucing sumput is traditional game that called hide and seek. In this game, ucing serves as a guard who must find his friends who are hiding (sumput). When the guard finds a friend who is hiding, the guard will shout 25 while calling the name of the friend. The friend whose name is called must come out of the hiding place. However, if a friend who is hiding can break through the place of ucing on guard then call the defender 25 then the ucing must be a guard again.

\section{Boy-boyan}

The boy-boyan game is played by two teams. One team is assigned as a thrower while the other team is assigned as a guard. Boy-boyan game requires a solid ball or paper shaped like a ball and small tile fragments. The throwing team will throw each other at a specified distance to knock down the tile stack. If the throwing team succeeds in breaking down the tile, the guard team must chase and direct the ball into the throwing team's body. While avoiding throwing the ball, the throwing team must reconstruct tile fragments. If the throwing team manages to arrange tile fragment then the player shouts BOY. Thus, the throwing team obtained one score. 
Oray-orayan

Oray-orayan is a cheerful game that combines elements of movement and sound. This sundanese traditional games are usually played by many children. How to play Orayorayan is that two children hold hands to form a gate then they choose to be "moon" or "star" (the players have to kept secret from the others). Other players line up while holding a friend's shoulder in front of him and walk through the gate. The front child is called the head and the back is called tail. Each player follows the steps of the upstream snake while singing.

\section{Oray-Orayan}

Oray orayan, luar léor mapay sawah, Entong ka sawah, Paréna keur sedeng beukah.

Orang-orayan

Luar-léor mapay kebon

Entong ka kebon, di kebon loba nu ngangon.

Mending gé ka leuwi, di leuwi loba nu mandi

Saha anu mandi

Anu mandina pandeuri.

Oray-orayan

Oray naon? Oray Bungka

Bungka naon? bungka laut

Laut naon? Laut dipa
Dipa naon? Dipandeuri riririri ...

When the end of the song "riririririri ... " The two players who became the gate lowered their hands and caught a player. Players who are caught must choose the moon or star. If the player chooses the month, he will stand behind the moon. The game continues until all players are caught so that it will form a moon team and a star team. Both teams will compete with each other by pulling each other's hands (like pulling a rope).

\section{Sondah}

Sondah is one of traditional game which is generally played by girls with a pattern of slatted boxes drawn on the ground. Each player held a piece of crumbling or flat stone, then a broken fragment was thrown into the box. The player jumps from the box to the next box. Boxes that contain broken pieces should not be stepped on. Players are defeated if they step on the box or outside of the box.

\section{Bebentengan}

Bebentengan require speed, agility and a good strategy to play this group game. Steps of Bebentengan namely a) before the game begins there is a lottery to divide the players 
into 2 groups, b) the team that wins the lottery starts the game by going out of the Benteng to lure opponents, d) each player functions as an angler or chased and also as a chaser. They will become the opponent's pursuer, if the opponent first leaves the Benteng and they will be the one who are chased by the opponent if they leave the Benteng last, e) the captured member will be the captive of the opposing party as well as vice versa, f) the way to capture is enough by touching body parts of opponents, g) prisoners gathered in the opposing area can be free again if the teammates who have not been caught can free by touching their body parts, h) the fortress one team is declared burned, if one of the opposing team sets one of his legs in the area Fortress of the opponent without any captivity in the Benteng, i) after one of Benteng's teams caught fire the game continued with the team that successfully burned as an angler, j) players who came out of the arena were considered caught so the score became 1-0.

\section{Galasin or Gobag Sodor}

Galasin or Gobag Sodor is a traditional game that requires dexterity and strategy. Steps to do this game are a) making guard lines with chalk like badminton courts but there are no double lines, b) dividing players into two teams consisting of 3 - 5 or can be adjusted to the number of participants. One team will be a "guard" team and the other team will be an "opponent" team, c) the team members who have a "guard" turn will guard the field, the way they are guarded is horizontal lines and there is also a vertical line. Horizontal line guards are in charge of blocking opponents who are also trying to cross the boundary line, d) the opposing team must try to pass the row to the back row, then back through the opponent's guard to the starting line, e) the opposing team is said to win if one team member succeeds return to the starting line safely (untouched by the opposing team), f) The "opposing" team is said to be defeated if one of its members is touched by the team "guard" or exit beyond the specified field boundary. If this happens, a position change will be made, namely the "opponent" team will become a "guard" team.

Traditional games are kind of games that only require simple support tools and categorized as traditions because they have the 
same intergenerational game patterns. Prawitasari explained that traditional games contain moral values such as cooperation, tolerance, empathy, reduce personal selfishness [25]. Therefore, traditional games are assumed to develop interpersonal ability of elementary school students.

\section{Methodology}

Action research was chosen as the method in this study. Action research begins with the emergence of an initial idea to improve a particular practice then followed by an understanding of the practice conditions through the collection of preliminary data to understand what actually happened so that with this understanding a plan will be prepared to take action in accordance with the changes desired by the researchers or practitioners involved in action research (Suharsaputra, 2014). This research applied collaborative action research which means researchers, practitioners, and students are involved in research (Banks, et.al, 2017). The study was located in one of the elementary schools in Cicalengka sub-district with 25 of fifth grade students as it's subjects. The reason for choosing fifth grade students as subjects because they are in a time of developing exploration with strong peers. The fifht grade students like to form groups in friendships so that relationships with friends outside the group are less solid. Therefore, through this study researchers want students to mingle with all friends so that their interpersonal ability will be developed.

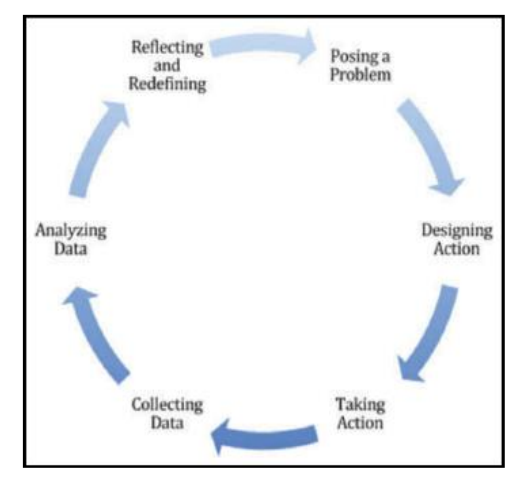

Figure 1. Action Research Flow

Figure 1 is an action research flow described by Ball and Cohen which explains that action research begins with identifying a problem (Ball and Cohen, 1999). Then the researcher looked for literature review and research results as a reference to deal with identified problems. After finding the right literature in problem solving, the researcher drew a design in the form of learning in the 
classroom or program that needs to be implemented on an ongoing basis. Furthermore, the practitioner implemented the design whose data will be taken during the action process (Netcoh, et.al, 2017). Data collection techniques in this research used observation and documentation. Observation is a data collection technique that is based on monitoring the processes that occur (Suharsaputra, 2014). The form of obtaining data from observations is directly from the field. The instrument used in the study used field notes within a rating scale. Meanwhile triangulation becomes a validity technique in this research.

After the data is collected, the researcher analyzed the data obtained through thematic analysis. Thematic analysis is a way to find data in a phenomenon or activity based on themes that emerge from general information (Boyatzis, 1998).
The researcher employes deductive thematic analysis whose steps consist of (a) recording all the data obtained, (b) determining the code based on the theory, (c) lowering the code in the appropriate theme, (d) matching the data with the codes and themes that have been determined, (e) evaluating and interpreting results. The final step in action research is to measure the achievement of actions that have been carried out and draw conclusions from the research.

\section{Results and Discussion}

\section{Result}

The study was conducted in six meetings. Students play different traditional games at each meeting. The teacher has been observing and measuring students' interpersonal ability that appear during traditional games. The percentage of each meeting is presented in the figure below. 


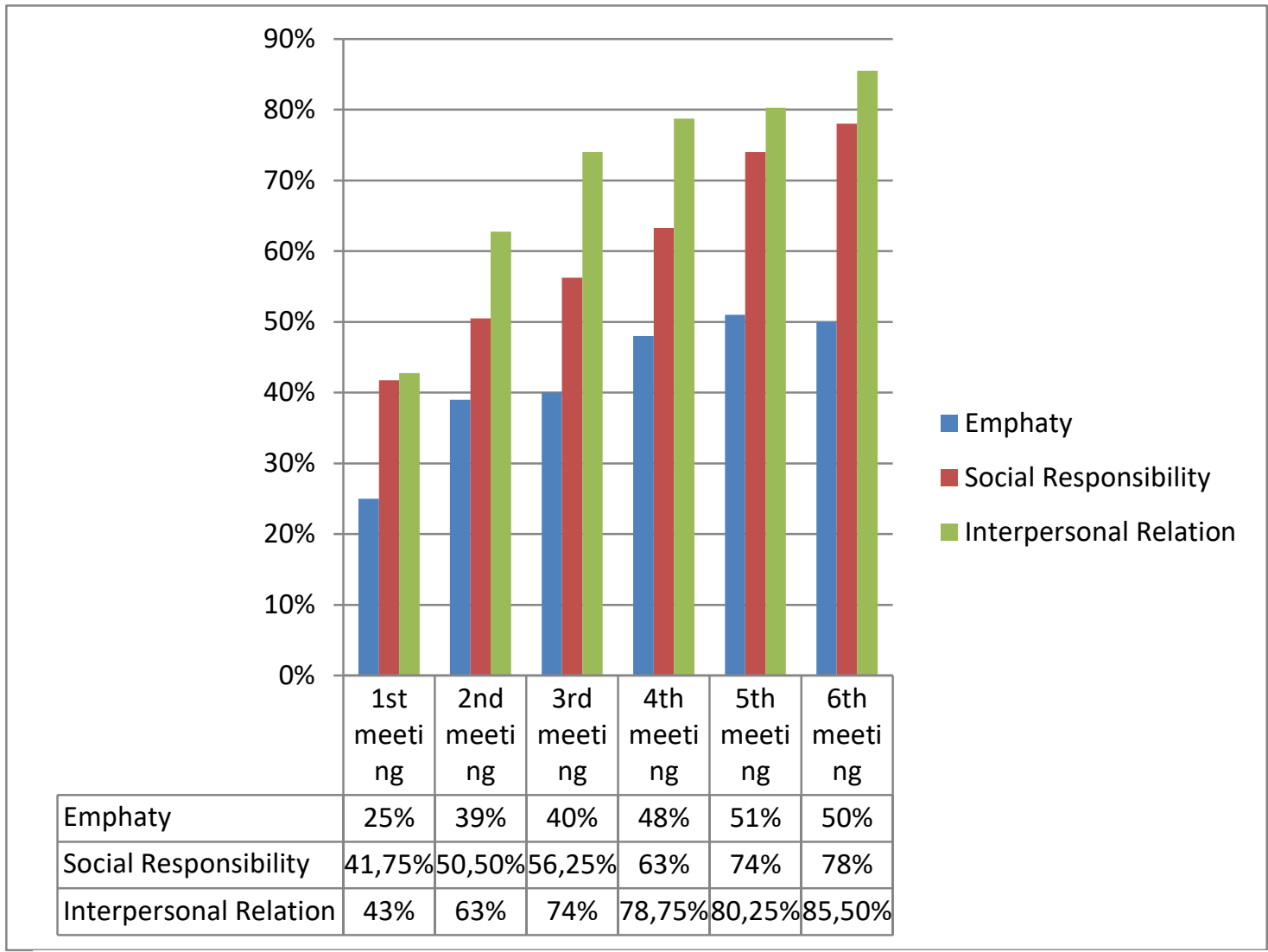

Figure 2. Percentage of Interpersonal Ability of Elementary Students

Figure 2 explains the acquisition of the percentage of students' interpersonal abilities for six meetings. Students played ucing sumput or hide and seek at the first meeting. Students made a lottery to determine guard or ucing. After the guard was determined, the guard was assigned to find his or her friends who were hiding. In this game, honesty and agility were needed. Interpersonal ability shown by students in this game were attitudes of responsibility and interpersonal relationships. Meanwhile, the attitude of empathy had not been seen game. There were students who cheated when playing ucing sumput. The student kept hiding even though the guard had found him. Other students who had been found sometimes interfered with the concentration of the guard by pretending to see a friend who was hiding or telling the whereabouts of another friend. Therefore, students' interpersonal abilities were categorized as not yet developed in every aspect.

Students played boy-boyan at the second meeting. Students' interpersonal abilitythat emerged in 
boy-boyan games were attitudes of responsibility and interpersonal relationships. Responsibility was shown when students took the initiative to make balls from rolls of paper, looked for broken tiles, and made boundary lines for throwing balls. The attitude of responsibility was still categorized as not yet developed because only a few students were involved in preparing the needs to play. Then, interpersonal relations were shown by students who could take part in the game and were able to work together with their groups. This attitude was categorized as developing because many students did cheating behavior during the game. Meanwhile, the attitude of empathy was also categorized as undeveloped because students had not shown empathy during the game.

The third meeting, the students played oray-orayan. This game is a physical fighting game so to win the game the students must have a strong physical. In oray-orayan, students' attitude that was the most common was interpersonal relationships. This was shown by students who tried hard to defeat the opposing team. The attitude of empathy was shown by students when they did not blame each other on their team for losing. Students still felt happy despite not winning the game.

Traditional game played at the fourth meeting was bentengan. Before playing, the teacher asked students to comment on traditional games that had been played. Some students commented if traditional games were not less interesting compared to mobile games. Students also explained that traditional games made them healthy because they moved a lot. Empathy was not shown in this game because this game involved more strategy and solidarity. Therefore, in this game, the attitudes of responsibility and interpersonal relationships had increased. The responsibility of the students was shown when they were able to play their role in the game. Meanwhile, the attitude of interpersonal relations was proven by students who were able to play in accordance with the rules and to follow the teacher's advice to be careful when playing. Students also did not cheat or made a riot when playing like they did at the first meeting.

Students played sondah at the fifth meeting. Before playing, the 
teacher gave a little explanation regarding traditional games in Indonesia. There are traditional Indonesian games that are almost similar in terms of playing rules but the name of the game is different. In Central Java the game sondah was given the name engklek. In Palembang, it was named cak engkle, while in Manado it was named enge-enge. The teacher also explained the importance of the community to preserve traditional games so they will not be claimed by other countries. All aspects of students' interpersonal ability were seen at the second meeting. All aspects also experienced a slight increase. An empathy attitude was seen when there was a student whose feet bled from stepping on broken tiles. Some students approached their injured friend while others cleaned the playing equipment. During the game, students patiently waited for their turn while watching their friends playing. When there were students who accidentally stepped on the line, students who were waiting for their turn had to admonish their friends. During the game, students showed a cooperative attitude. They were able to accept reprimands when they accidentally made mistakes and were able to play in an orderly manner. This indicated that students could control their emotions better and could be honest. Thus, interpersonal ability were categorized as starting to develop in students.

In the final meeting, students played galasin or gobak sodor. Since students were getting used to playing traditional games, they could adjust to the rules of the game although there were still most students who showed disturbing behavior such as cheating, interfering with the opposing team, or not receiving a friend's reprimand. However, aspects of interpersonal ability were increasing in the final meeting. The attitude of empathy for students had begun to develop while the attitude of student responsibility was categorized as developing according to expectations. Meanwhile, the attitude of interpersonal relations students developed very well. Each competing group was quite fierce. Various ways were done to break the concentration of the group so they did not successfully break through the opponent's defense. The teacher as the referee was in charge of 
regulating the course of the match and reprimanding students who provoked too much. The game was exciting and students were seen enjoying the traditional games they had done. After the game was over, the teacher asked the students about their feelings about the traditional game that had been done. Students simultaneously answered that they were very happy to play on the field and wanted to continue playing. The teacher also asked the students about their opinions on the benefits of traditional games. Some students explained that traditional games trained cooperation, strategic thinking, and solidarity.

Based on the research results that had been described, the researcher indicated that traditional games could develop students' interpersonal ability. Students' interpersonal ability increased at each meeting. Students' empathy attitudes were categorized as developing. The attitude of student responsibility was categorized as developing according to expectations, while the attitude of student interpersonal relations developed very well. Each student showed different developments. Female students showed a better attitude of responsibility than male students. Meanwhile, interpersonal relations between male students and female students showed the same development. However, male students were better at being game leaders and managing play strategies.

\section{b. Discussion}

Playing facilitates elementary school students to learn to participate actively, to develop self-confidence, and to form good relationships with groups (Fan, 2012). In elementary school students, learning really needs to be integrated with playing so that the cognitive, affective, and psychomotor aspects of students develop more easily. According to Hurlock game patterns that can motivate students' social development are games with social nuances. This social nuance can be found in traditional games (Hurlock, 2012). Traditional games are one of the playing activities that can be applied easily to students. Traditional games offer many benefits for students in building communication, collaboration, and interpersonal ability. 
This study aims at building the interpersonal ability of elementary school students through traditional games. Traditional games chosen in this study were ucing sumput, orayorayan, sondah, boy-boyan, bentengan, and gobag sodor. The game of ucing sumput, oray-orayan, and sondah was useful to internalize honesty, teamwork and agility. Traditional games sharpened children's emotional support skills such as forming empathy and making efforts to help friends who experienced difficulties.

This attitude of empathy was shown by students when a friend's foot hit broken tiles and then they helped their friend and stopped the game. Then, the game boy-boyan, bentengan, and gobag sodor is a game that requires cooperation, contains elements of competition, has rules, and requires strategy (Susanti, dkk, 2010). The game with elements of competition, rules, and strategies are categorized as quality games. Competition games stimulate students to be brave and quick to decide what steps to take in the game. The competition contributes to stimulating children in collaborating with teammates in an effort to achieve the game's goals (Puolin \& Chan, 2010).

At the beginning of the meetings, the research showed poor results. Most students showed an attitude of unwillingness, high individualism, cheating, and lack of interaction with their teammates. The results of the study proved that student interpersonal ability were still low. The low level of students' interpersonal ability was triggered by students' incomprehension with traditional games. This is in line with the opinion of Lavega, Alonso, Etxebeste, Lagardera, and March who explains that most students exhibit an unfavorable attitude of cooperation between groups because the value of traditional games has been lost (Lavega, et.al, 2014). Traditional games had been replaced by online games that make students passive in every activity. Therefore, students needed to be reintroduced to traditional games because traditional games offered many benefits such as helping physical growth, developing social skills, and student interpersonal ability .

At the next meeting, students' interpersonal ability experienced a slight improvement, especially in 
aspects of interpersonal relationships and responsibilities. Meanwhile, the attitude of empathy was still not developed in students. Students were better in mingling with their groups and discussing strategies to be applied in the game. Students also began to be able to control themselves to accept reprimands or not to cheat in the game although there were still some who liked cheating. Students' interpersonal ability that began to develop were caused by traditional games' rules that had to be obeyed by students. Through traditional games, students learned to obey the rules that affected students' attitudes towards rules in various places. In addition, traditional games helped students to socialize more easily with their peers. Traditional games also developed students' analytical skills because they needed to develop strategies and to appreciate the differences of opinion that arose. This was in line with the opinion of Marcone, Caputo, and Monica who explains that playing teaches students to forgive the mistakes of others and to build an attitude of cooperation and communication with those around them (Marcone, et.a;, 2015). For students, playing is a physical activity, a means of learning, and a way to have fun and express themselves.

Furthermore, at the fifth and sixth meeting, students played traditional games that required playing strategies. Students' interpersonal ability in the two final meetings showed good results. The attitude of the student's responsibility developed as expected while the attitude of interpersonal relations developed very well. The attitude of interpersonal relations was reflected when students were discussing in planning the strategies. According to Hasanah and Hardiyanti (2016), the formulation of strategies in traditional games is a means for students to practice the ability to overcome internal conflicts within the group. Correspondingly, Kovacevic and Opic (2014) explains that traditional games affect the cognitive aspects of students when they think of strategies and analyze the opponent's game. Traditional games are flexible so students can make their own playing rules without changing the outline of the game pattern. In this study, students made a mutual agreement before the game started and obeyed 
the agreement until the game was over. Fan add that the game provides opportunities for students to get along with peers and to learn to recognize various rules to adjust to their environment.

The results showed that traditional games could develop students' interpersonal ability. Alcock (2016) conducted a study related to the influence of playing on early childhood interpersonal abilities [39]. The results of Alcock's study showed that playing influences the interpersonal abilities of early childhood. At an early age, interpersonal ability are very important to be developed because children learn to care not only for themselves but also for others and their surroundings. Playing affects children's emotional formation when they interact with their peers. Children learn to distinguish interactions between peers and adults. This proved that playing was effective against the development of children's interpersonal ability.

In addition, this study was supported by the results of research by Susanti, Siswati, \& Widodo which proved that traditional games had an effect on students' interpersonal abilities with peers. In this study, each student showed the development of different interpersonal abilities. Female students showed a better attitude of responsibility than male students. Meanwhile, interpersonal relations between male students and female students showed the same development. However, male students were better at being game leaders and managing play strategies. The development of different interpersonal abilities was influenced by gender. This was in line with the opinion of Lavega, Alonso, Etxebeste, Lagardera, and March, which states that girls tend to be more oriented to interpersonal relationships while boys are more masculine and competitive. Novitasari also adds the explanation that gender affects the way of socializing, verbal ability, and behavior (Nivitasari, 2017). Male students are genetically more aggressive so when they play they often cheat, do not want to lose, and do a little physical action. Meanwhile, female students tend to be cooperative and affiliative (Dufour \& Curtis, 2011). This attitude was shown by female students when they tried to follow the rules, were involved in the provision of game tools, and 
were able to control emotions in the game.

Traditional games have elements that affect various aspects of student development. Traditional games have good moral values because this game comes from local culture so traditional games are categorized as cultural assets that need to be preserved. Dharmamulya explains that traditional games contain elements of value that can be internalized in students such as the value of friendship, democracy, responsibility, and mutual help that are useful in community life (Dhamamulya, 2008). Therefore, traditional games applied in learning are not only useful for developing students' interpersonal ability but as a means to introduce students to the culture of the nation. Traditional games are cultural manifestations that need to be preserved. They allegedly contribute to building positive relationships for children and adults because they do not depend on age and gender (Sahay, 2013).

\section{E. Conclusion}

The patterns of playing and learning of elementary school students has significant changes.
This is due to technological developments that are so rapid and affect student development. The positive impact of technology is that it allows students to gain knowledge and hone their creativity. However, the negative impact of technology also has a significant influence on student development. Technological addiction causes students to be less sensitive to people and the surrounding environment so that their interpersonal abilities become low. Therefore, schools as a form of personality building for students need to facilitate students with learning that is full of moral values. Traditional games are alleged to be one way to facilitate the development of students' interpersonal ability. Through traditional games students know the game with elements of physical activity, groups, and strategy formulation. Traditional games are very useful for the development of students' interpersonal ability. This is evidenced by the results of research that shows students' interpersonal ablity has developed in each meeting. The problem in this study is that not all traditional games can be played in teams. Due to the large number of students can lead to a less conducive 
atmosphere. Therefore, the researcher suggests that teachers can adjust the type of traditional game with the number of students. In addition, teachers also need to introduce traditional games that come from other regions as a way to preserve culture and develop students' interpersonal ability.

\section{REFERENCES}

Agustin, D. (2013). Permainan Tradisional sebagai Media Simulasi Aspek Perkembangan Anak Usia Dini. Bayumedia

Alcock, S.J. (2016). Interpersonal Fields of Play. Early Child Development Care. 5 (6). 924-934

Andriani, T. (2012). Permainan Tradisional dalam Membentuk Karakter Anak Usia Dini. Jurnal Sosial Budaya. 9 (1), 121-136

Ball, D.L., and Cohen, D.K. (1999). Developing Practice, Developing Practitioners: Toward Practice Based Theory of Professional Education. In Darling-Hammond L., and Sykes, G. (Eds), Teaching as The Learning Profession Josey Bass Publishers 332.

Banks, S., Herrington, T., Carter, K. (2017). Pathways to Co Impact: Action Research and Community Organising. Educational Action Research. 25 (4), 541-559
Berger, E.H., and Cortez, M.R.R. (2012). Parents as Partners in Education: Families and Schools Working Together. Pearson

Boyatzis, R.E. (1998). Transforming Qualitative Information. Cleveland

Boyd, D. (2014). It's Complicated: The Social Lives of Networked Teens. Yale : University Press

Dharmamulya, S. (2008). Permainan Tradisional Jawa. Kepel Press

Dufour, B., and Curtis, W. (2011). Studying Education: An Introduction to the Key Disciplines in Education Studies. Mc Graw Hill

Fan, F.A. (2012). Teacher: Students' Interpersonal Relationships and Students' Academic Achievements in Social Studies. Teachers and Teaching: Theory and Practice. 18 (4), 483-490

Goh, W., Bay, S., and Chen, V.H.H. (2015).Young School Children's Use of Digital Devices and Parental Rules", Telematics and Informatics. 32 (4). 787-795.

Hakim, A.R. (2018). Kecerdasan Interpersonal Siswa melalui Model Student Teams Achievement Divisions. Elementary School Education Journal. 2 (1), 51-58

Hasanah, N.I., and Hardiyanti, P. (2016). Pengembangan Anak melalui Permainan Tradisional. Aswaja Pressindo

Hayati, F., and Julia. (2018). 
Hurlock, E.B. (2012). Perkembangan Anak Jilid I. Jakarta : Erlangga

Isangedighi, (2007). J.,.Child Psychology Development and Education. Eti-Nwa

Joyce, B., and Weill, M. (2013). Models of Teaching. Prentice Hall

Khilmiyah, A. (2011). Evaluasi Implementasi Pendidikan Karakter pada Sekolah Dasar Percontohan Pendidikan Karakter di Kabuoaten Bantul. LP3M

Kovacovic, T., and Opic, S. (2014). Contribution of Traditional Games to the Quality of Students' Relations and Frequency of Students' Socialization in Primary Education. Croation of Journal Education. 16 (1). 95-112

Lavega, P., Alonso, J.I., Etxebeste, J., Lagardera, F., and March, J., (2014). Relationship between Traditional Games and the Intensity of Emotions Experienced by Participants. Research Quarterly for Exercise and Sport. 85 (4), 457-467

Lee, S.J., (2013). Parental Restrictive Mediation of Childrens' Internet Use: Effective for What and for Whom?, New Media Soc. 15, 466-481

Lestari, W., and Siregar, N. (2017). Peranan Permainan Tradisional Engklek dalam Mengembangkan Keterampilan Sosial Anak Usia Sekolah Dasar di Desa Hamparan Perak. Science Education Journal. 7 (3), 305-311.

Marcone, R., Caputo, A., Monica, C.D. (2015). Friendship Competence in Kindergarten and Primary School Children. European Journal of Development Psychology. 12 (4), 412-428

Martin, R.A., "The Psychology of Humor: An Intregative Approach", Elsevier Academic Press (2007).

Netcoh, S., Olofson, M.W., Downes, J.A., and Bishop, P.A. (2017). Professional Learning with Action Research in Innovative Middle Schools. Middle School Journal. 48 (3), 25-33

Novitasari, N.I. (2017). Optimalisasi Manajemen Intervensi Kelas terhadap Perilaku Buruk Siswa di Madrasah Ibtidaiyah. Manageria: Jurnal Manajemen Pendidikan Islam. 2 (1), 63-80

Padykula, N.L., and Horwitz, M., (2012). Using Psychodinamic Concepts to Measure Interpersonal Competencies during Social Work Training. 9 (1), 48-61

Peningkatan Kemampuan Interpersonal melalui Permaainan Balon Berpasangan di Kelompok Bermain PAUD Bina Insani Kemala Bhayangkari 1 Banda Aceh. Jurnal Buah Hati. 5 (1), 63-71

Poulin, F., and Chan, A. (2010). Friendship Stability and Change in Childhood and Adolescene, Developmental Review. 30, 257-272

Prawitasari, M. (2016). Nilai-nilai Permainan Tradisional Mayarakat Banjar. In the Proceedings of International Seminar on 
Ethnopedagogy, FKIP UNLAM Press 277-284

Safaria, (2005). Education Games. Flash Book.

Sahay, S. (2013). Traditional Children's Games of Bihar. Electronic Journal of Folklore. 54. 119-136

Sahin, D., (2011). Preschoolers, Preschool Teachers, and Problem Solving Skills: A Comparative Study in Turkey nad Belgium, Education 313: International Journal of Primary, Elementary, and Early Years Education .39 (3). 305-316

Siregar, M.M. (2014). Penerapan Metode Sosiodrama untuk Meningkatkan Kemampuan Interpersonal Siswa Kelas VII SMP Negeri Depok Sleman Yogyakarta. Jurnal Bimbingan dan Konseling. 3 (4), 1-11.

Sparrow, T., and Knight, A. (2006). Applied El: The Importance Attitudes in Developing Emotional Intelligence. John Willey and Sons

Strader, T.J. (2011). Digital Technology in 21st Century, In Troy, J.S. (Eds). Digital Product of Management, Technology, and Practice: Interdisciplinary Perspectives, Business Science Reference, 235-262.

Suharsaputra, U. (2014). Metode Penelitian Kuantitatif, Kualitatif, dan Tindakan. Refika Aditama

Sundari, S.A. (2015). Pengaruh Keaktifan dalam Kepramukaan terhadap Kecerdasan Interpersonal
Siswa Kelas V SD di Gugus Sugarda, Jurnal Pendidikan Guru Sekolah Dasar. 3 (4), 1-8

Susanti, F., Siswati, and Widodo, B. (2010). Pengaruh Permainan Tradisional terhadap Kompetensi Interpersonal dengan Teman Sebaya pada Siswa SD. Jurnal Psikologi Undip. 8 (2), 145-155

Syahniar. (2008). Tindak Pembelajaran yang Berkontribusi terhadap Peningkatan Kemampuan Interpersonal Siswa Sekolah Dasar, Jurnal IImu Pendidikan. 15 (2). 128134

Taufik. (2013). Pengembangan Kemampuan Interpersonal Siswa melalui Layanan Bimbingan Kelompok. Pedagogi Jurnal IImiah IImu Pendidikan. XIII (1), 91-99

Tim Playplus Indonesia (TPI). (2017). Ensiklopedia Permainan Tradisional Anak Indonesia. Jakarta : Erlangga 